\title{
Bioaccumulation Capacity and Antimicrobial Activity of Turbinaria ornata (Turner) J. Agardh
}

\author{
M. A. Deyab \\ Botany Department, Faculty of Science, Damietta University
}

Tel: +20.57.2403866; Fax: +20.57.2403868, email: modeyab@yahoo.com

\begin{abstract}
The present study investigated the chemical composition and biological activities of the brown macroalga, Turbinaria ornata. The biochemical analysis of Turbinaria ornata indicated that there was a relative high protein, lipids, polysaccharides and carotenoids recorded during November; while the relative high soluble carbohydrate and chlorophylls were recorded during September. Heavy metals ( $\mathrm{Pb}, \mathrm{Zn}, \mathrm{Fe}, \mathrm{Cd}, \mathrm{Mn}, \mathrm{Cu}$ and $\mathrm{Co}$ ) accumulated 6-22 times in T. ornata more than that in surrounding water with relative increases during November. Antimicrobial activities of ethanol extract of $T$. ornata as well as oleic acid, palmitic acid, fucoxanthin and fucosterol (extracted from the alga) were directly proportional to concentrations and varied with the growth stage of the alga as well as with the type of microb. These extracts showed high antibacterial activities particularly against Escherichia coli and Bacillus subtilis. Moreover the extracts exhibited high antifungal activities especially against Aspergillus niger and fusarium oxysporium. Scanning microscope showed that mixtures of oleic and palmitic acids caused plasmolysis and reduction in cell size of Escherichia coli, and malformation and swelling in conidiophore and spores of Aspergillus niger. On the other hand, cytotoxic activity using cultured mammalian cell lines indicated that the highest activity was recorded by fucoxanthin followed by fucosterol, and ethanol extract of $T$. ornata. These cytotoxic activities were directly proportional with the extract concentrations.
\end{abstract}

Keywords: antimicrobial activity, bioaccumulation, biochemical content, cytotoxicity, Turbinaria ornata

\section{Introduction}

The present study investigates the chemical composition and biological activities of the brown macroalga, Turbinaria ornata (Kingdom Chromalveolata, Division Heterokontophyta, Class Phaeophyceae, Order Fucales, Family Saragassaceae [1]). On coral reef, Turbinaria ornata dominates subtidal and reef crest environments [2]. Density of $T$. ornata, length of thallus, length of blade, amount of blade, and dry weights greatly varied among sites and seasons. Its highest growth was found in October on the semi-exposed shore in Thailand $[3,4]$.

Turbinaria ornata shows great variation in nutrient contents, organic materials and nutritive elements which are related to several environmental factors [5,6]. While some trace elements are considered toxic such as $\mathrm{As}, \mathrm{Br}, \mathrm{Cd}$, $\mathrm{Hg}, \mathrm{Pb}, \mathrm{Sb}$ and others are considered essential $(\mathrm{Cu}, \mathrm{Zn})$ to human body $(\mathrm{Cr}, \mathrm{Se})$ [7]. Turbinaria ornata was distinctive for its high content of alginic acid. It is a complex carbohydrate polymer consisting of D-mannuronic acid and L- 
guluronic acid residues linked by 1-4 positions [8]. Fucosterol is the most abundant phytosterol in brown algae and is responsible for cytotoxic effect of their extracts [9]. Fucoxanthin is a type of carotenoid found naturally in dibble brown seaweed and diatoms. It has formula $\mathrm{C}_{42} \mathrm{H}_{58} \mathrm{O}_{6}$ [10]. Turbinaria ornata extract was active against Gram positive and negative bacteria; Aeromonas hydrophila, Enterococcus faecalis, Escherichia coli, Proteus vulgaris, Pseudomonas aeruginosa, Shigella flexneri and Staphylococcus aureus [11]. Several results indicated that the extracts contained different antibacterial substances that reflected the diversity of secondary metabolites [12-14]. The present study aimed at investigating the biochemical contents, bioaccumulation capacity and antimicrobial activities of Turbinaria ornata.

\section{Materials and methods}

\section{Sample collection}

Water samples were collected during autumn in September, October and November 2011 from the semi- exposed shores of Hurghada, Red seaEgypt (Fig. 1). Turbinaria ornata and other associated seaweeds were collected during low tide at Red Sea shore, using a quadrant measuring $1 \mathrm{~m}^{2}$ area and weighing the fresh weight for quantitative assessment of abundance.

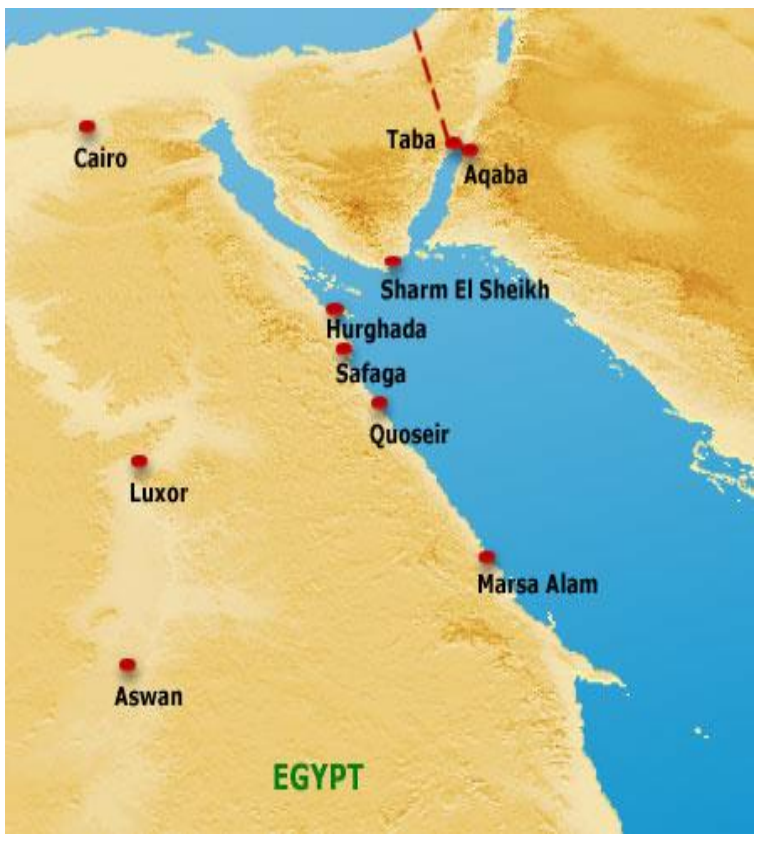

Fig. 1 A map showing the collection sites along shores of Hurghada

\section{Physico-chemical analysis of water}

Temperature, $\mathrm{pH}$, turbidity and salinity were measured in situ. Dissolved oxygen was measured in laboratory according to Manivasakam [15]. Biochemical oxygen demand (BOD) was determined by the method described by APHA [16]. Sulphates and nitrates $\mathrm{NO}_{3}-\mathrm{N}$ were determined according to Trivedy and Goel [17]. Alkalinity was determined according to Sunil kumar et al. [18]. Ammonia was determined according to Dawes et al. [19]. Inorganic phosphates were determined according to APHA [16]. Heavy metals $(\mathrm{Cu}, \mathrm{Co}, \mathrm{Zn}, \mathrm{Fe}, \mathrm{Mn}, \mathrm{Cd}$ and $\mathrm{Pb}$ ), in water sample were determined according to Floyd and Hezekiah [20].

\section{Biochemical analysis of Turbinaria ornata}

Turbinaria ornata was washed with tap water and distilled water to remove all the salt on the surface. The seaweed was shade dried, kept in an oven at $60^{\circ} \mathrm{C}$ for $4 \mathrm{hrs}$, ground and stored in polyethylene bags at room temperature.

The dried algal materials were digested according to Khanzada et.al [21]. The protein content was determined spectrophotometrically according Bradford [22]. Total carbohydrate was determined spectrophotometrically using Anthrone method according to Hedge and Hofreiter [23]. Lipids content was determined according to Bligh and Dyer [24]. Heavy metals $(\mathrm{Cu}, \mathrm{Co}, \mathrm{Zn}, \mathrm{Fe}, \mathrm{Mn}, \mathrm{Cd}$ and $\mathrm{Pb})$ were determined in the digested samples according to Floyd and Hezekiah [20]. Alginic acid was determined by the Sodium alginate method according to Dawes [25] and by the Calcium alginate method according to Dawes [26]. Agar was extracted from $T$. ornata as described by Pickering et al. [27]. Pigments (Chla, Chlb and carotenoids) in $T$. were extracted according to the method described by Kumar et.al. [28], determined and calculated according to the formula of Lichtentaler and Wellburn [29].

\section{Extraction of oleic and palmitic acids from $T$. ornate}

Separation of oleic acid (monounsaturated fatty acid) and palmitic acid (saturated fatty acids) was carried out according to Fulco [30] using Reversed Phase High Performance Liquid Chromatography (RP-HPLC). The chromatography model, Agilent technologies 1200 series was used. 
Extraction of fucosterol and fucoxanthin from Turbinaria ornata

Four kilograms of air dried Turbinaria ornata was extracted with chloroform: methanol (1:1). The extract was evaporated under reduced pressure to afford a dark brown viscous oily residue (100 g, 2.5\% dry weight). This was mounted on a silica packed column and eluted using successively $\mathrm{n}$ - hexane- $\mathrm{Et}_{2} \mathrm{O}$, n-hexaneEtOAc and $\mathrm{CHCl}_{3}-\mathrm{MeOH}$ gradient. Fractions of $50 \mathrm{ml}$ were collected. The fractions were afterwards subjected to gel permeation on Sephadex LH-20 (MeOH: $\left.\mathrm{CHCl}_{3}, 1: 1\right)$ to obtain steroid and carotenoid- enriched fractions which were finally purified by preparative TLC $\left(\mathrm{CHCl}_{3}: \mathrm{MeOH}, 9.5: 0.5\right)$ giving fucosterol and fucoxanthin [31]. Fucosterol and fucoxanthin were determined and identified by NMR application.

Assay of antimicrobial activities of ethanol extract, fatty acids and fucosterol and fucoxanthin of Turbinaria ornata

Ten, 30, 50, 80 and $100 \mathrm{~g}$ of the air dried powder of Turbinaria ornata were extracted in a soxhlet extractor for $8 \mathrm{~h}$ with of ethanol $(95 \%)$ the extract was raised up to one liter of ethanol to prepare ethanol extract of $T$. ornata with concentrations of $10,30,50,80$ and $100 \mathrm{mg} \mathrm{ml}^{-1}$.

Oleic acid, palmitic acid, fucosterol and fucoxanthin which extracted from T. Ornata were dissolved and diluted in ethanol to concentrations of 10, 30, 50, 80 and $100 \mathrm{mg} \mathrm{ml}^{-1}$. Each dilution of these natural products as well as ethanol extract of $T$. ornata were dropped onto sterile filter paper disc (5 mm diameter) and dried for 30 min under aseptic conditions.

For the control, ethanol was used. These discs were then incubated for $24 \mathrm{~h}$ at $37^{\circ} \mathrm{C}$ with the bacteria species Bacillus subtilis, B. cereus, Staphylococcus aureus Escherichia coli and Klebsiella pneumonia or for $5-7$ days at $28^{\circ} \mathrm{C}$ with the fungal species Fusarium oxysporium, Alternaria alternata, Aspergillus niger and Penicillium notatum. The used bacteria and fungi were kindly obtained from Microbiology laboratory Faculty of Science Damietta University. The activity assays were replicated in triplicates. After incubation, the clear zones around the discs were measured in millimeters taking into consideration the clear zones around the discs in control dishes. Moreover a mixture of
$50 \mathrm{mg} \mathrm{ml}^{-1}$ oleic acid and palmitic acid (1:1) was used to assay their antimicrobial effects on vegetative structure of $E$. coli and A. niger. Both organisms were further examined using Jeol, JSM-5300 scanning electron microscope.

Assay of cytotoxicity activities of ethanol extract of Turbinaria ornata as well as fucosterol and fucoxanthin

The Swiss mouse embryo fibroblast (NIH 3T3) and the virally transformed mouse fibroblast (KA3IT) cell lines were kept in Dulbecco's Modified Eagle's Medium and supplemented with $10 \%$ fetal bovine serum (FBS). $100 \mathrm{mg} \mathrm{ml}^{-1}$ penicillin and $100 \mathrm{mg} \mathrm{ml}^{-1}$ streptomycin were added to the media. All cell lines were cultured at $37^{\circ} \mathrm{C}$ for $24 \mathrm{~h}$ in air/carbon dioxide (95/5) atmosphere. Each concentration of ethanol extract of Turbinaria ornate, fucoxanthin and fucosterol which extracted from $T$. ornata was tested for each cell line. Fucoxanthin and fucosterol were dissolved in Dimethyl Sulfoxide (DMSO) and diluted with cell culture medium. Cells with no treatment were examined as negative control. Cell viability was determined as follows: after $96 \mathrm{~h}, 20$ $\mu \mathrm{l}$ of 3-(4,5-Dimethylthiazol-2-yl)-2,5diphenyltetrazolium bromide reagent $\left(5 \mathrm{mg} \mathrm{ml}^{-1}\right)$ in phosphate buffered serum (PBS) was added to each well. The plates were allowed to proliferate and their exponential phase of growth. The plates were incubated at $37^{\circ} \mathrm{C}$ for $4 \mathrm{~h}$. At the end of the incubation period, the medium was removed and $100 \mu \mathrm{l}$ cell DMSO was added to each well. The formazan salts were quantified by reading the absorbance at $550 \mathrm{~nm}$. Cell viability in assays was calculated as a percentage of untreated cells (control value). The cytotoxicity value was presented as $\mathrm{IC}_{50}$ (the median growth inhibitory concentration) that were calculated by Sigmaplot (10) software [32].

Data were statistically analyzed for variance and the least significant difference (LSD) using one-way analysis of variance (ANOVA). A software system SPSS version 13 was used for these calculations.

\section{Results and Discussion}

The present study showed that the mean total covering flora of sea weeds at Hurghada site was about $32 \%$ of quadrate meter. The macroalgal community contained 23 species (Phaeophyta 12 species, 7 genera, Chlorophyta 6 species, 5 
genera and Rhodophyta 5 species, 4 genera) and sea grass (Halophila sp) (Table 1). Negm [33] recorded 57 species of seaweeds (18 belong to Phaeophyta, 18 species belong to Chlorophyta and 21 species belong to Rhodophyta) which inhabiting the Egyptian Red Sea coast at Hurghada. This variation in seaweed flora may be due to that the present study was occurred out only in autumn season, besides the increase of tourism activity. Generaly, Phaeophytaen species of genus Trbenaria, Sargassum and Cystosira form the massive growth of sea weeds at Hurghada during autumn monthes followed by rhodophytene species of genus Lurancia (Table1).The quantitative abundance (\% of total fresh weight) of sea weeds species at Hurghada (Table1). In the present result the highest growth of Turbinaria ornata was during October (24\%), followed by November (21.5\%) and septamber (18\% of total fresh weight) (Table 1). In this respect the highest Turbinaria ornata growth was found in October on the semi-exposed shore in Thailand $[3,4]$.

Table 1. Quantitative abundance of the seaweeds species at Hurghada in the autumn monthes of 2011 (\% of total fresh weight)

\begin{tabular}{|c|c|c|c|}
\hline Species & Sept & Oct & Nov \\
\hline \multicolumn{4}{|l|}{ Chlorophyta } \\
\hline \multicolumn{4}{|l|}{ Ulotrichales } \\
\hline Enteromorpha compressa (L.) grev & 0.5 & 0.5 & 0.5 \\
\hline \multicolumn{4}{|l|}{ Siphonocladiales } \\
\hline $\begin{array}{l}\text { Pajinea fingralist kutz } \\
\text { Pullernales }\end{array}$ & 1.0 & 0.5 & 0.5 \\
\hline Caulerpa racemosa (forsk.). Ag. & 15 & \multicolumn{2}{|c|}{ caulerpales } \\
\hline Caulerpa spirales (Mont.) & 1.5 & 1.0 & 1.0 \\
\hline & 1.0 & - & - \\
\hline Codium dichotomum (Huds.) Gray. & 1.0 & - & - \\
\hline Halimeda tuna (Ell. Sel.). lamour. & 2.0 & 1.0 & - \\
\hline \multicolumn{4}{|l|}{ Phaeophyta } \\
\hline \multicolumn{4}{|l|}{ Dictyotales } \\
\hline Dictyota dichotoma (Huds.) lomour. & 1.0 & 2.0 & 2.0 \\
\hline Padina boryana (Thirvy.) & 0.5 & 1.0 & 2.0 \\
\hline Padina pavonica (Linnaeus) Thivy. & 0.5 & 1.0 & 1.0 \\
\hline \multicolumn{4}{|l|}{ Dictyosiphonales } \\
\hline Colpomenia sinuosa (Roth.).Derb. et. Sel. & 1.0 & 0.5 & - \\
\hline Hydroclathrus clathratus (Bory.) Howe. & 1.0 & 1.0 & - \\
\hline \multicolumn{4}{|l|}{ Fucales } \\
\hline Cystoseira myrica (Gmel)J.Ag & 14 & 15.4 & 15.8 \\
\hline Cystoseira trinode (Forsk.) J.Ag. & 9.0 & 8.0 & 12.5 \\
\hline Sargassum latifolium (Turn.) Ag. & 12.0 & 10.0 & 11.8 \\
\hline Sargassum crispa (forsk.) Ag. (2) & 16.5 & 17.0 & 18.5 \\
\hline Turbinaria triquetra (C.Ag.)AG. & 3.0 & 4.5 & 4.0 \\
\hline Turbinaria turbinate (L) Kuntze & 2.0 & 4.5 & 4.0 \\
\hline Turbinaria ornata & 18.5 & 24.0 & 21.5 \\
\hline \multicolumn{4}{|l|}{ Rhodophyta } \\
\hline \multicolumn{4}{|l|}{ Cryptonemiales } \\
\hline Corallina tenella (Kutz.) Heydr. & 1.0 & 1.0 & 1.0 \\
\hline Jania rubens (L.)lamour. & 1.0 & 1.0 & 1.0 \\
\hline \multicolumn{4}{|l|}{ Ceramiales } \\
\hline Dijenia simplex (Wulfen.).C.Ag. & 5.0 & 2.4 & 1.2 \\
\hline Laurencia obtuse (Huds.) lamour. (3) & 5.0 & 2.0 & 1.3 \\
\hline Laurencia papillosa (Forsk.) Grev & 2.0 & 1.7 & 0.4 \\
\hline
\end{tabular}

\section{Physicochemical analysis}

The physicochemical analysis of seawater indicated that all parameters were not varied significantly among sampling months and suitable for algal growth (Table 2). This may be due to the relative stability of ecological parameters of Red Sea during study period (autumn months).

As shown in Table 2 there was a relative decrease of temperature, total alkalinity and salinity from September to November, parallel with Egyptian climate; where water evaporation 
decreased and ran off beginning during October and increased during November [6]. Temperature usually affects the growth stages of macroalgae as tide level [34]. Moreover, low degree of turbidity, high DO and low BOD may be due to low water pollution and low wave action at the study area. Dissolved oxygen in water affects the oxidation- reduction state of nutrients and diversity of aquatic biota [15].

Low content of phosphate, nitrate and ammonia indicated the oligo-mesotrophic status of water. Unpolluted natural water contains only minute amounts of nitrate [17].

Table 2. Physicochemical analysis of water

\begin{tabular}{cccccccccc}
\hline $\begin{array}{l}\mathrm{T} \\
\left({ }^{\circ} \mathrm{C}\right)\end{array}$ & $\mathrm{PH}$ & $\begin{array}{l}\text { Turb } \\
(\mathrm{NTU})\end{array}$ & $\begin{array}{l}\text { Tot alk } \\
\left(\mathrm{meq}^{-1}\right)\end{array}$ & $\begin{array}{l}\text { Salinity } \\
\left(\mathrm{g} \mathrm{l}^{-1}\right)\end{array}$ & $\begin{array}{l}\mathrm{DO} \\
\left(\mathrm{mg} \mathrm{l}^{-1}\right)\end{array}$ & $\begin{array}{l}\mathrm{BOD} \\
\left(\mathrm{mg} \mathrm{l}^{-1}\right)\end{array}$ & $\begin{array}{l}\mathrm{NO}_{3}^{-} \\
\left(\mathrm{mg} \mathrm{l}^{-1}\right)\end{array}$ & $\begin{array}{l}\mathrm{NH}^{+} \\
\left(\mathrm{mg} \mathrm{l}^{-1}\right)\end{array}$ & $\begin{array}{l}\mathrm{PO}^{---} \\
\left(\mathrm{mg} \mathrm{l}^{-1}\right)\end{array}$ \\
\hline Sept 27 & $7.8 \pm 0.05$ & $13.9 \pm 0.06$ & $2.9 \pm 0.06$ & $41.0 \pm 0.0412 .3 \pm 0.15$ & $1.7 \pm 0.01$ & $0.07 \pm 0.001$ & $0.8 \pm 0.01$ & $0.29 \pm 0.01$ \\
Oct 25 & $8.3 \pm 0.06$ & $13.6 \pm 0.05$ & $2.6 \pm 0.05$ & $40.4 \pm 0.0412 .6 \pm 0.17$ & $1.6 \pm 0.01$ & $0.07 \pm 0.001$ & $0.7 \pm 0.01$ & $0.28 \pm 0.01$ \\
Nov 24 & $8.4 \pm 0.05$ & $13.5 \pm 0.04$ & $2.3 \pm 0.05$ & $40.1 \pm 0.0512 .9 \pm 0.12$ & $1.6 \pm 0.01$ & $0.05 \pm 0.001$ & $0.7 \pm 0.01$ & $0.27 \pm 0.02$ \\
\hline
\end{tabular}

\section{Biochemical analysis of Turbinaria ornate}

As shown in Table 3, The relative high polysaccharides, carotenoids, protein and lipids in Turbinaria ornata were recorded during mature stage of alga in November; while the relative high chlorophylls, and soluble carbohydrate was recorded during the high growth rate of alga in September .In the present study, the relative low content of protein, lipids and carbohydrate in $T$. ornata than that obtained by Manivasakam et al. [15] may be due to the relative low trophic (oligo- mesotrophic) status of the Red Sea water and variation of other environmental factors [6].

The chlorophyll a content was more constant in Turbinaria ornata during study period. this was related to that $\mathrm{Chl}$ a is essential pigment for photosynthesis in photoautotrophic marine algae $[35,36]$; while the decreasing of chlorophyll b content was alternated with the increase of carotenoids content gradually from September, October and November . This was in parallel with increasing the maturation state of $T$. ornate $[3,4]$.

Table 3. Biochemical analysis of Turbinaria ornata ( $\left.\mathrm{mg} \mathrm{l}^{-1} \mathrm{dry} \mathrm{wt}\right)$

\begin{tabular}{llllllllll}
\hline & Protein & $\begin{array}{l}\text { Soluble } \\
\text { carb }\end{array}$ & $\begin{array}{l}\text { Lipid } \\
\text { Alginate }\end{array}$ & $\begin{array}{l}\text { Na- } \\
\text { alginate }\end{array}$ & Ca- & Agar & Chl a & Chl b & Car \\
\hline Sept & $32.3 \pm 1.7$ & $2.8 \pm 0.3$ & $2.5 \pm 0.05$ & $198 \pm 2.5$ & $306 \pm 3.2$ & $83 \pm 1.5$ & $0.019 \pm 0.001$ & $0.0016 \pm 0.001$ & $0.012 \pm 0.006$ \\
Oct & $35.4 \pm 0.6$ & $2.4 \pm 0.1$ & $2.6 \pm 0.05$ & $242 \pm 3.4$ & $378 \pm 3.1$ & $102 \pm 1.2$ & $0.02 \pm 0.001$ & $0.0011 \pm 0.001$ & $0.013 \pm 0.002$ \\
Nov & $37.7 \pm 0.6$ & $2.2 \pm 0.2$ & $3.1 \pm 0.06$ & $253 \pm 2.8$ & $393 \pm 2.5$ & $117 \pm 2.5$ & $0.019 \pm 0.003$ & $0.0009 \pm 0.001$ & $0.015 \pm 0.004$ \\
\hline
\end{tabular}

Natural products such as Na- alginate, $\mathrm{Ca}$ alginate and agar contents in T. ornata of Red Sea were was lower than that obtained by Younisi et al. [8] in T. ornata of Eritrea (Rocky intertidal area). This was due to difference in wave action and possibly other environmental parameters that can affect algal growth. Generally the present results are in agreement with Younisi et al. [8] that the Calcium alginate method gave higher percentage yield of alginic acid than the Sodium alginate method.

The bioaccumulation capacity of $T$. ornata for several heavy metals varid between 6-22 times than that found in surrounding water (Table 4). The variation of accumulation capacity may be due to the variation of T.ornata requirements for heavy metals bioconsuption, as well as variation of other biological activities of algal cell in relation to heavy metal type. The ability of $T$. ornata to accumulate heavy metals may be attributed to the presence of charged polysaccharides in the cell walls $[37,38]$. The results showed that heavy metals content in $T$. ornata was relatively higher in November than in September. This can be attributed to the longterm variation of heavy metal level in the marine environment [39]. Meanwhile, the heavy metal content in water relatively decreased from September to November, this were mainly related to relative decrease of temperature, salinity and other environmental factors.

\section{Antimicrbial activity of Turbinaria ornata extracts}

The average limit of five different concentrations 
of $T$. ornata ethanol extract over the five tested bacteria and the four tested fungi were ranged between $0.5 \mathrm{~mm}$ against $E$. coli to $5.5 \mathrm{~mm}$ against $B$. subtilis $\mathrm{mm}$ and $0.4 \mathrm{~mm}$ against $F$. oxysporium to $3 \mathrm{~mm}$ against $A$. niger respectively (Table 5). The antimicrobial activity of $T$. ornata was previously reported by some studies [13,14].

Table 4. Heavy metals content in water $\left(\mathrm{mg} \mathrm{l}^{-1}\right)$ and in Turbinaria ornata ( $\mathrm{mg} \mathrm{kg}^{-1}$ fresh weight)

\begin{tabular}{lllllllll}
\hline \multirow{2}{*}{ Sept } & $\mathrm{Pb}$ & $\mathrm{Zn}$ & $\mathrm{Fe}$ & $\mathrm{Cd}$ & $\mathrm{Mn}$ & $\mathrm{Cu}$ & $\mathrm{Co}$ \\
& water & 0.80 & 0.56 & 0.55 & 0.70 & 0.33 & 1.12 & 0.62 \\
\multirow{3}{*}{ Oct } & T. ornata & 6.20 & 6.40 & 4.60 & 9.90 & 5.10 & 6.70 & 8.50 \\
& water & 0.74 & 0.51 & 0.49 & 0.60 & 0.29 & 1.07 & 0.59 \\
\multirow{3}{*}{ Nov } & T. ornata & 6.60 & 6.50 & 4.70 & 10.50 & 5.50 & 7.10 & 8.80 \\
& water & 0.70 & 0.47 & 0.46 & 0.50 & 0.26 & 10.30 & 0.54 \\
& T. ornata & 7.00 & 6.90 & 4.90 & 11.00 & 5.80 & 7.50 & 9.40 \\
\hline
\end{tabular}

Antimicrobial activities of oleic acid extracted from $T$. ornate at $100 \mu \mathrm{g} \mathrm{ml}^{-1}$ showed higher values about $5 \mathrm{~mm}$ and $3.1 \mathrm{~mm}$ against $B$. subtilis and $F$. oxysporium, respectively. Palmitic acid extracted from $T$. ornata also showed high antimicrobial activities at concentration of 100 $\mu \mathrm{g} \mathrm{ml}^{-1}$ against B. cereus and A. niger (Table 5).

Interestingly, a mixture of oleic and palmitic acids (1:1) extracted from $T$. ornata showed strong antimicrobial activities with clear zone diameters of $9.5 \mathrm{~mm}$ and $7.5 \mathrm{~mm}$ against $B$. cereus and A. niger, respectively. Strauch et al. [40] explained the effect of oleic acid on Bacillus subtilis as mono unsaturated fatty acids, which can inhibit one of the protein kinases, KinA that affects the initiation of sporulation in B. subtilis. Furusawa and Koyama [41] found that addition of unsaturated fatty acids such as oleic acid caused the instantaneous depolarization of the membrane potential of the bacterium, Bacillus which appears to result in the drastic decrease of viability.

Oleic acid has antimicrobial effect over a wide spectrum of yeasts, a good number of Aspergillii, Penicillii, and many other moulds [42]. The palmitic acid has shown inhibition on the spore of Bacillus cereus [43]. In the present study, fucosterol extracted from $T$. ornata highest values were exhibited high antimicrobial activities at $100 \mu \mathrm{g} \mathrm{ml}^{-1}$ against $B$. subtilisi and A. niger (clear zones $=5.8 \mathrm{~mm}$ and $3.5 \mathrm{~mm}$, respectively). Fucosterol also exhibited antifungal activity it has been represented that had antifunction of activity fucosterol against Curvularia lunata, Stachybotrys atra and Microsporum canis [44].

Antimicrobial activities of fucoxanthin extracted from $T$. ornata showed that the highest values were $7 \mathrm{~mm}$ and $4.5 \mathrm{~mm}$ recorded by 100 $\mu \mathrm{g} \mathrm{ml}^{-1}$ fucoxanthin against $B$. subtilis and $A$. alternatar, respectively.

Table 5 shows that mixtures of oleic and palmitic acids (1:1) recorded the highest antimicrobial activity against all tested organisms, followed by fucoxanthin, fucosterol, oleic acid, palmitic acid and ethanol extract of $T$. ornata. Moreover, their antimicrobial activities increased significantly (LSD at 0.01 level) with increasing concentrations.

Furthermore, scanning electron microscope indicated that mixtures of oleic and palmitic acids can cause plasmolysis and reduction in cell size of $E$. coli as well as malformation and swelling in conidiophore and spores of Aspergillus niger (Fig. 2).

Antimicrobial effects of fucosterol and fucoxanthin may be related to their cytotoxicity effect. Their antibacterial activities against Gram positive bacteria were higher than that against Gram negative bacteria.

The results presented in Table 6 indicate that generally the cytotoxic activity of fucoxanthin were higher than that of fucosterol and ethanol extract by about $31 \%$ by using KA3IT fibroblast cell line and about $96 \%$ by using NIH3T3 fibroblast in Cultured Mammalian Cell Lines. The cytotoxic activity was directly proportional to the concentrations of ethanol extract of Turbinaria ornata and fucsosterol and fucoxanthin where, the maximum toxicity recorded at $100 \mu \mathrm{g}$ $\mathrm{ml}^{-1}$ from all extracts. Moreover, cytotoxic activity of fucoxanthin more than $\mathrm{IC}_{50}$ at concentration $=80 \mathrm{mg} \mathrm{ml}^{-1}$.

Fig. 2 shows that scanning electron microscope indicated that mixtures of oleic and palmitic acids caused plasmolysis and reduction in cell size of $E$. coli. Moreover it causes malformation and swelling in conidiophore and spores of Aspergillus niger. 
Table 5. Antimicrobial activity of Turbinaria ornata extract, oleic acid, palmitic acid, their mixtures, fucosterol and fucoxanthin extracted from $T$. ornata (width of inhibition zone (mm))

\begin{tabular}{|c|c|c|c|c|c|c|c|c|c|}
\hline \multirow[t]{2}{*}{$\mathrm{mg} \mathrm{ml}^{-1}$} & \multicolumn{5}{|c|}{ Antibacterial species } & \multicolumn{4}{|c|}{ Antifungal species } \\
\hline & $\begin{array}{l}\text { E. } \\
\text { coli }\end{array}$ & $\begin{array}{l}B . \\
\text { cereus }\end{array}$ & $\begin{array}{l}\text { B. } \\
\text { subtilis }\end{array}$ & $\begin{array}{l}\text { K. } \\
\text { pneum }\end{array}$ & $\begin{array}{l}S . \\
\text { aureus }\end{array}$ & $\begin{array}{l}P . \\
\text { notatum }\end{array}$ & $\begin{array}{l}A . \\
\text { niger }\end{array}$ & $\begin{array}{l}\text { A. } \\
\text { alternata }\end{array}$ & $\begin{array}{l}F . \\
\text { oxysporium }\end{array}$ \\
\hline \multicolumn{10}{|c|}{ T. ornata ethanol extract } \\
\hline 10 & 0.5 & 1.6 & 1.7 & 0.6 & 0.8 & 0.5 & 0.8 & 0.6 & 0.4 \\
\hline 30 & 0.8 & 2.5 & 2.6 & 1.0 & 1.4 & 1.0 & 1.2 & 1.1 & 0.7 \\
\hline 50 & 1.2 & 3.5 & 3.5 & 1.5 & 2.0 & 1.5 & 1.7 & 1.5 & 1.0 \\
\hline 80 & 2.1 & 4.2 & 4.4 & 2.5 & 3.1 & 1.7 & 2.3 & 2.0 & 1.7 \\
\hline 100 & 3.0 & 5.0 & 5.5 & 3.5 & 4.0 & 2.0 & 3.0 & 2.5 & 2.5 \\
\hline \multicolumn{10}{|l|}{ Oleic acid } \\
\hline 10 & 1.5 & 1.5 & 2.5 & 1.0 & 0.5 & 1.0 & 1.5 & 0.5 & 1.5 \\
\hline 30 & 2.2 & 1.7 & 3.0 & 1.2 & 1.0 & 1.3 & 1.7 & 1.0 & 2.0 \\
\hline 50 & 3.0 & 2.0 & 3.5 & 1.5 & 1.5 & 1.5 & 2.0 & 1.5 & 2.5 \\
\hline 80 & 3.2 & 3.2 & 4.2 & 1.8 & 2.0 & 1.7 & 2.5 & 2.0 & 2.6 \\
\hline 100 & 3.5 & 4.5 & 5.0 & 2.0 & 3.5 & 2.0 & 3.0 & 2.5 & 2.8 \\
\hline \multicolumn{10}{|c|}{ Palmitic acid } \\
\hline 10 & 0.5 & 2.5 & 2.0 & 0.5 & nil & 0.5 & 1.5 & 0.5 & 1.0 \\
\hline 30 & 0.8 & 3.5 & 2.2 & 0.7 & 0.5 & 0.7 & 2.0 & 0.5 & 1.2 \\
\hline 50 & 1.0 & 4.5 & 2.5 & 1.0 & 1.0 & 1.0 & 2.5 & 0.6 & 1.5 \\
\hline 80 & 1.7 & 4.7 & 3.0 & 1.5 & 2.0 & 1.2 & 2.8 & 1.0 & 1.8 \\
\hline 100 & 2.5 & 5.0 & 3.5 & 2.0 & 3.0 & 1.5 & 3.0 & 1.5 & 2.0 \\
\hline \multicolumn{10}{|c|}{ Oleic and palmitic (1:1) } \\
\hline 10 & 2.5 & 5.0 & 4.5 & 2.0 & 2.0 & 2.0 & 4.0 & 2.5 & 3.0 \\
\hline 30 & 3.0 & 6.0 & 5.2 & 2.8 & 3.0 & 2.7 & 4.5 & 3.2 & 3.5 \\
\hline 50 & 3.5 & 7.0 & 6.0 & 3.5 & 4.0 & 3.5 & 5.0 & 4.0 & 4.0 \\
\hline 80 & 4.5 & 8.5 & 8.0 & 4.5 & 5.5 & 5.0 & 6.5 & 5.0 & 5.0 \\
\hline 100 & 5.5 & 9.5 & 9.2 & 6.0 & 6.5 & 6.0 & 7.5 & 6.2 & 6.5 \\
\hline \multicolumn{10}{|l|}{ Fucosterol } \\
\hline 10 & 0.5 & 1.5 & 1.7 & 0.8 & 1.0 & 0.5 & 0.5 & 0.8 & 0.5 \\
\hline 30 & 1.0 & 2.5 & 2.7 & 1.2 & 1.5 & 1.4 & 1.0 & 1.5 & 1.0 \\
\hline 50 & 1.3 & 3.8 & 3.8 & 1.7 & 2.2 & 2.0 & 1.3 & 1.7 & 1.3 \\
\hline 80 & 2.5 & 4.5 & 5.0 & 2.3 & 3.3 & 2.2 & 2.5 & 2.0 & 1.8 \\
\hline 100 & 3.4 & 5.5 & 5.8 & 3.7 & 4.5 & 2.4 & 3.5 & 2.2 & 2.3 \\
\hline \multicolumn{10}{|c|}{ Fucoxanthin } \\
\hline 10 & 0.5 & 2.0 & 1.7 & 1.0 & 1.5 & 1.5 & 0.5 & 1.5 & 0.5 \\
\hline 30 & 1.0 & 3.5 & 3.3 & 1.5 & 2.0 & 2.0 & 1.0 & 2.0 & 1.0 \\
\hline 50 & 1.5 & 5.0 & 5.5 & 2.6 & 3.5 & 2.3 & 2.2 & 2.5 & 2.3 \\
\hline 80 & 3.5 & 6.0 & 6.7 & 3.5 & 4.5 & 2.8 & 3.4 & 3.3 & 3.0 \\
\hline 100 & 4.0 & 6.5 & 7.0 & 4.8 & 5.3 & 2.9 & 4.2 & 4.0 & 3.5 \\
\hline
\end{tabular}

Table 6. Cytotoxic activity of ethanol extract of Turbinaria ornata and compounds fucosterol and fucoxanthin $\left(\mu \mathrm{g} \mathrm{g}^{-1}\right.$ dry wt) in Cultured Mammalian Cell Lines

\begin{tabular}{|c|c|c|c|c|c|c|c|c|c|c|c|c|c|c|c|}
\hline Conc & & & nol e & ract & & & & cost & & & & & dxan & & \\
\hline$\overline{\mu \mathrm{g} \mathrm{ml}^{-1}}$ & $\overline{10}$ & 30 & 50 & 80 & 100 & 10 & 30 & 50 & 80 & 100 & 10 & 30 & 50 & 80 & 100 \\
\hline NIH37 & & & & & & & & & & & & & & & \\
\hline & 7 & 10 & 21 & 26 & 31 & 7.5 & 11 & 22 & 26 & 33 & 13 & 20 & 41 & 52 & 62 \\
\hline KA3I' & & & & & & & & & & & & & & & \\
\hline & 3 & 4.5 & 9 & 11 & 13.5 & 1.5 & 2.5 & 5 & 6.5 & 8 & 3.5 & 5 & 11 & 14 & 17 \\
\hline
\end{tabular}

\section{Conclusion}

The highest growth of Turbinaria ornate was in October (24\% of total fresh weight of sea weeds) at Hurghada. The biochemical contents of Turbinaria ornate (chlorophylls, carotins, charbohydrates, lipids and proteins) varied according to growth stage. Bioaccumulation 
capacities (6-22 times) of T. ornata for heavy metals depend on types of heavy metals and growth stage of $T$. ornata. The relative high

(i)

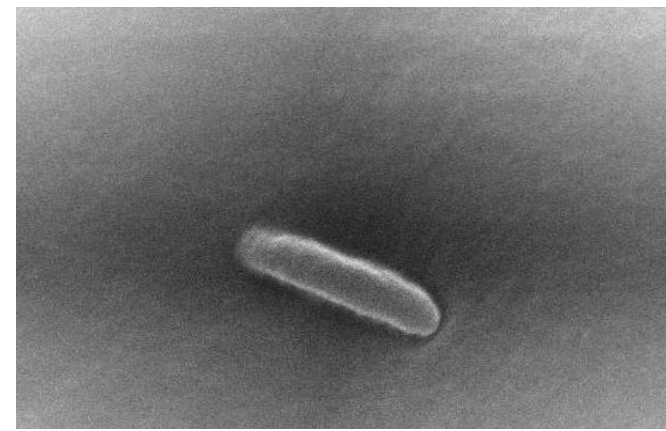

(iii)

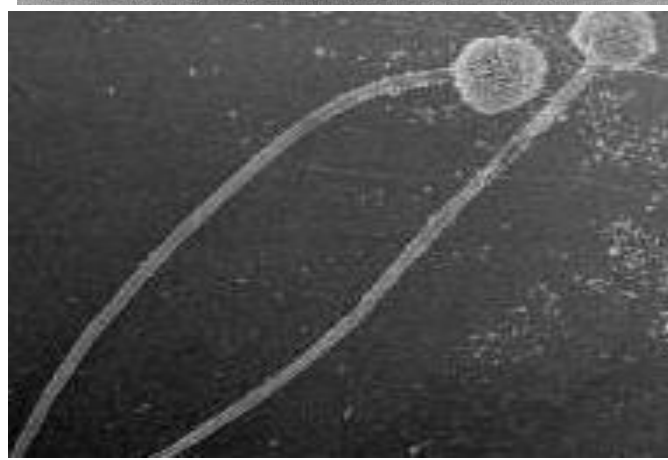

(ii)

(iv)

antibiotic activity of $T$. ornata were against gram positive bacteria specially Escherichia coli,Bacillus subtilis and B cereus.

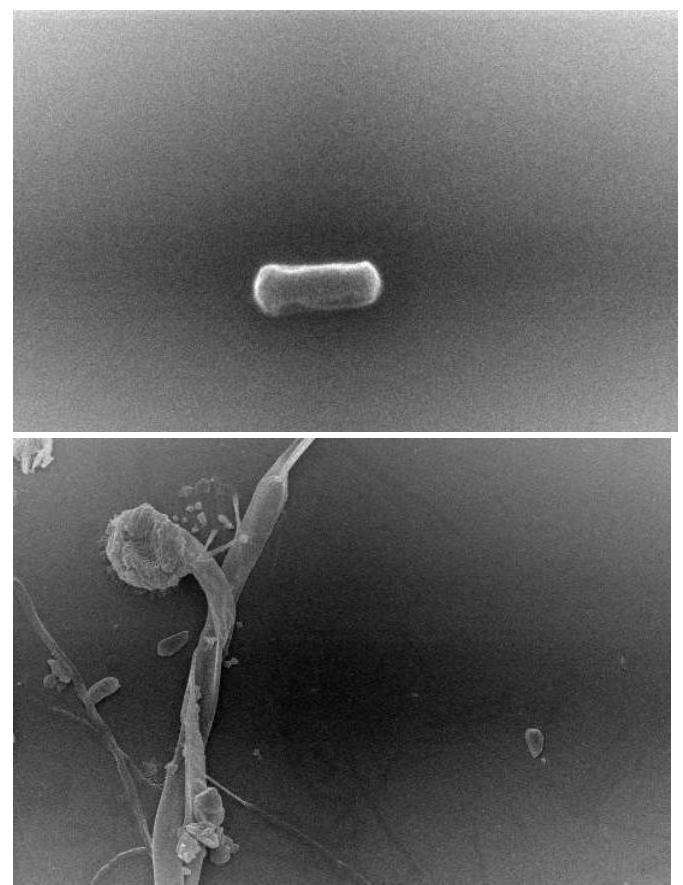

Fig. 2 Electronic microscope phpotographs showing the effects of mixture of oleic acid and palmitic acid (1:1) on E. coli and Aspergillus niger. (i) E. coli Control, (ii) E. coli affected by the mixture (iii) Aspergillus niger Control, (iv) Aspergillus niger affected by the mixture.

The relative high antifungal activities were against Aspergillus niger and Fusarium oxysporium. Mixture of oleic and palmitic acids recorded the highest antimicrobial activity against all tested organisms, followed by fucoxanthin, fucostrol, oleic acid, palmitic acid and ethanol extract of T. ornata. Moreover, their antimicrobial activities increased significantly (LSD at 0.01 level) with concentrations and varied according to type of microbos. Scanning microscope showed that mixtures of oleic and palmitic acids (1:1) caused plasmolysis and reduction in cell size of $\mathrm{E}$. coli, and malformation and swelling in conidiophore and spores of Aspergillus niger. The highest cytotoxic activity was recorded by fucoxanthin followed by fucosterol, and ethanol extract of T. ornata.

\section{References}

[1] M.D. Guiry, G.M. Guiry, Algae base.World-wide electronic publication.National University of Ireland. Galway 53 (2011) 160

[2] D.J. Russell, G.H. Balazs, Identification manual for dietary vegetation of the Hawaiian green turtle, Chelonia mydas. NOAA TM-NMFS-
SWFSC-294 (2000) 49

[3] H.L. Stewart, Hydrodynamic consequences of maintaining an upright posture by different magnitudes of stiffness and buoyancy in the tropical alga Turbinaria ornata. J. Mar. Sys. 49 (2004) 157

[4] V. Stiger, C. Payri, Natural settlement dynamics of a young population of Turbinaria ornata and phonological comparisons with older populations. Aquat. Bot. 81 (2005) 225

[5] C.J. Dawes, Marine Botany. John Wiley \& Sons, Inc. New York, (1998) 480

[6] J. Flurence, Seaweed proteins: Biochemical, nutritional aspects and potential uses. Trends in Food Sci. Techol. 10 (1999) 25

[7] A. Forsberg, S. Soederlund, A. Frank, L.R. Petersson, M. Derson, Studies on metal content in the brown sea-weed, Fucus vesiculosus from the Archipelago of Stockholm. Environ. Pollut. 49 (1988) 63

[8] Y.M.H. Younisi, S. Tecleab, T. Gheza, I.H. Rahama, Determination of the biomass and phycocolloid contents of some marine algae from Eritrea. Vol. 11 (2000) 19

[9] M. Khanavi, R. Gheidarloo, N. Sadati, M.R.S. Ardekani, S.M.B. Nabavi, S. Tavajohi, S.N. Ostad, Cytotoxicity of fucosterol containing fraction of marine algae against breast and colon carcinoma cell line. 8 (2012) 60 
[10] J. Peng, J.P. Yuan, C.F. Wu, J.H. Wang, Fucoxanthin, a marine carotenoid present in brown seaweeds and Diatoms: Metabolism and Bioactivities Relevant to Human Health. Mar. Drugs (2011) 1806

[11] G.M.L. Patterson, D.L. Parker, C.M. Bolis, Fungal cell wall polysaccharide elicits an antifungal two metabolite (phytoalexin) in the cyanobacterium Scytonema ocellatona. J. Phycol. 33 (1994) 54

[12] A. Gonzalez Del Val, G. Platas, A. Basilio, J. Gorrochategui, I. Suay, F. Vicente, E. Portillo, M. Jimenez Del Rio, R.G. Garcia, F. Pelaez, Screening of antimicrobial activities in red, green and brown macroalgae from Gran Canaria (Canary Islands, Spain). Int. Microbial. 4 (2001) 35

[13] I. Chiheb, R. Hassane, M.L. José, D.S.J. Francisco, G.V.J. Antonio, B. Hassan, K. Mohamed, Screening of antibacterial activity in marine green and brown macroalgae from the coast of Morocco. Afr. J. Biotechnol. 8 (2009) 1258

[14] N. Srivastava, K. Saurav, V. Mohanasrinivasan, K. Kannabiran, M. Singh, Antibacterial potential of macroalgae collected from the Mandapam coast, India. British J. Pharmacol. Toxicol. 1 (2010) 72

[15] N. Manivasakam, Industrial effluents: Origin, characteristics, effects, analysis and treatment. Sakthi publications, Coimbatore (1997)

[16] American Public Health Association (APHA), Standard methods for the examination of water and wastewater. Washington, DC. 18 (1992)

[17] R.K. Trivedy, P.K. Goel, Practical methods in ecology and environmental science. Environmental publications, Karad, India (1987)

[18] M. Sunil Kumar, R. Shailaja, Water studies: Methods for monitoring water quality. Center for Environmental Education, Bangalore (1998)

[19] E.A. Dawes, D.J. McGill, M. Midgley, Methods in Microbiology 5B (1971) 3

[20] W.B. Floyd, S. Hezekiah, Analysis of coal ash by atomic absorption spectrometric and spectrophotometric methods. In: Method for Sampling and Inorganic Analysis of Coal.USA. Geological Survey Bulletin 1823. D.W. Golightly, F.O. Simon (Ed) (1997) 1

[21] M.M. Bradford, A rapid and sensitive method for the quantification of microgram quantities of protein utilizing the principle of protein dye binding. Analytical Biochemistry 72 (1976) 248

[22] J.E. Hedge, B.T. Hofreiter, In: Carbohydrate Chemistry, 17 (Eds. R.L. Whistler, J.N. Be Miller), Academic Press, New York (1962)

[23] E.G. Bligh, W.J. Dyer, A rapid method of total lipid extraction and purification. Can. J. Biochem. Phsiol. 37 (1959) 911

[24] A.K. Khanzada, W. Shaikh, T.G. Kazi, S. Kabir, S. Soofia, Antifungal activity, elemental analysis and determination of total protein of seaweed, Solieria robusta (Greville) from the coast of Karachi, Pak. J. Bot. 39 (2007) 931

[25] C.J. Dawes, The biology of commercially important marine algae. Develop. Aquacult. Fish. Sci. 16 (1987) 155

[26] C.J. Dawes, Marine Botany. John Wiley and Sons, Inc., New York (1981)

[27] T.D. Pickering, M.E. Gordon, L.J. Tong, Seasonal growth, density, reproductive phonology and agar quality of Gracilaria sordida at Mokomotko inlet, New Zealand. Hydrobiol. 205 (1990) 253

[28] P. Kumar, C.M. Ramakritinan, A.K. Kumaraguru, Solvent extraction and spectrophotometric determination of pigments of some algal species from the shore of Puthumadam, Southeast Coast of India 4 (2010) 29

[29] H.K. Lichtenthaler, A.R. Welburn, Determination of total carotenoids and chlorophyll $\mathrm{a}$ and $\mathrm{b}$ of leaf in different solvents. Biol. Soc. Trans. 11 (1985) 591

[30] A.J. Fulco, The biosynthesis of unsaturated fatty acids by Bacilli. J. Biol. Chem. 245 (1970) 2985

[31] J.H. Sheu, G.H. Wang, P.J. Sung, C. Duh, Planta Med. 63 (1997) 571

[32] M. Khanavi, M. Nabavi, N. Sadati, M.S. Ardekani, J. Sohrabipour, S. M. Nabavi, P. Ghaeli, S.N. Ostad, Cytotoxicity activity of some marine brown algae against cancer cell lines. Biol. Res. 43 (2010) 31

[33] S.N.M. Negm, Ecological, biological and phytochemical studies on some marine algae from the Red Sea coast of Egypt. Ph.D. Thesis, Cairo University, Egypt (1988)

[34] G.C. Trono, G.L. Tolentino, The reproductive phenology of Sargassum sp. (Fucales, Phaeophyta) in Bolinao pangasinan. H.P. Incolumporg, E.G. Menez (Eds), Proc. 2nd RpUSA phycology Symp. Work shop. Philippine Council for Aquatic and Marine Research and Development, Los Banos. Laguna (1992) 181

[35] J.H. Martin, R.M. Gordon, S.E. Fiztwater, The Case for Iron. Bull. Fac. Sci. KAU. 36 (1991) 1793

[36] M.F. Grung, M.L. D’souza, M. Borowitzka, Algal carotenoids. 1. Secondary carotenoids. J. Appl. Phycol. 4 (1992) 165

[37] L.T. Salgado, L.R. Andrade, G.M. Amado Fihlo, Localization of specific monosaccharides in cells of the brown algae Padina gymnospora and the relation to heavy metal accumulation. Protoplasm. 225 (2005) 128

[38] M. Farina, C.N. Keim, J. Correa, L.R. Andrade, Microanalysis of metal accumulating biomolecules. Microanal J. 9 (2003) 1512

[39] R. Villares, X. Puente, A. Carballeira, Seasonal variation and background levels of heavy metals in two green seaweeds. Environ. Pollut. 119 
(2002) 79

[40] M.A. Strauch, D. de Mendoza, J.A. Hoch, Department of Molecular and Experimental Medicine, Scripps Research Institute, La Jolla, California 920376 (1992) 2909

[41] H. Furusawa, N. Koyama, Effect of fatty acids on the membrane potential of an alkaliphilic Bacillus. 48 (2004) 196

[42] W.S. Davidson, R.K. Saxena, R. Gupta, The fungistatic action of oleic acid. Current Sci. J.
76 (1999) 1137

[43] J. Zheng, Z. Li, L. Yuan, H. Zhong, Review on the physiological effects of areca nut use. Food Sci. Technol. 11 (2006) 302

[44] A. Atta-Ur-Rahman, M. Iqbal Choudhary, A. Majeed, M. Shabbir, U. Ghani, M. Shameel, A succinylanthranilic acid ester and other bioactive constituents of Jolyna laminarioides. (1997)

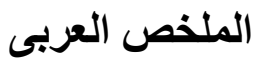

\title{
المحتوى البيوكيميائى وقدرة التراكم الحيوى ونشاط مقاومة الميكروبات لطحلب تربيناريا
}

\author{
محمد دياب \\ قسم النبات ـ كلية الطلوم - جامعة دمياط
}

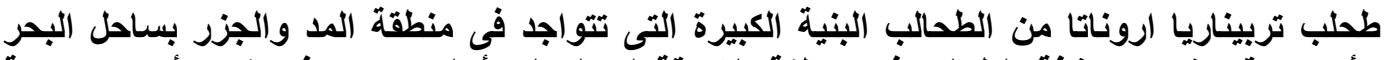

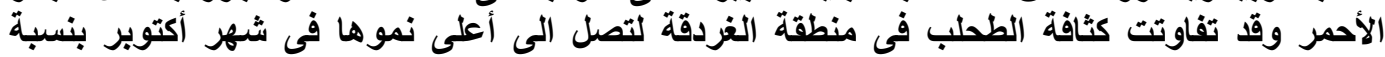

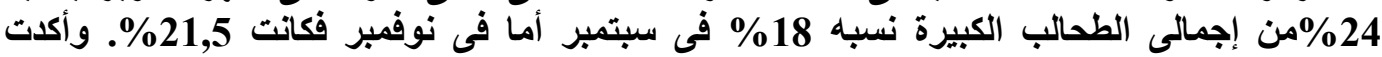

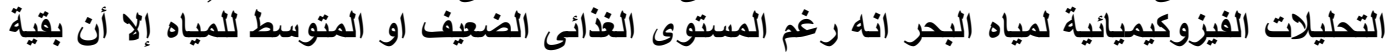

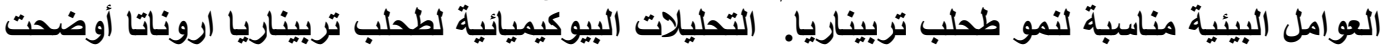

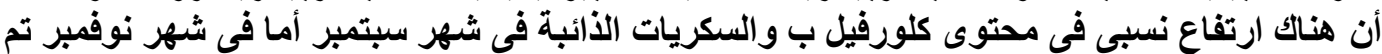

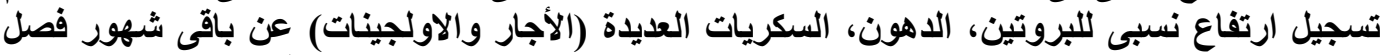

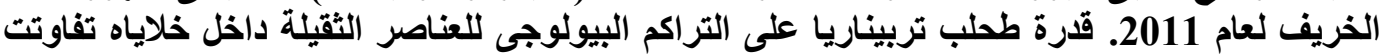

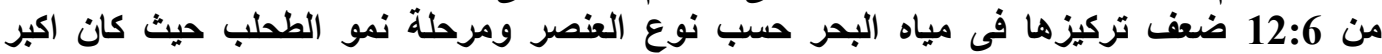

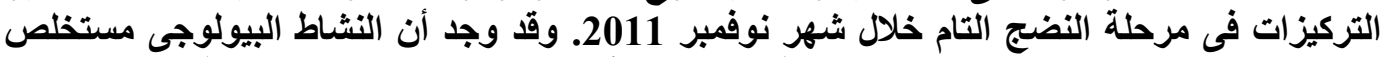

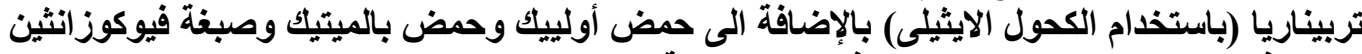

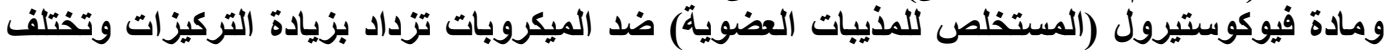

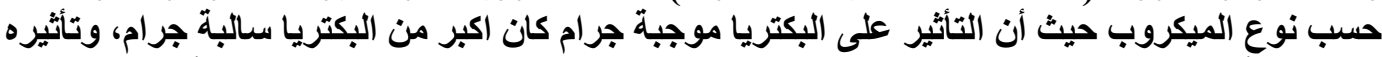

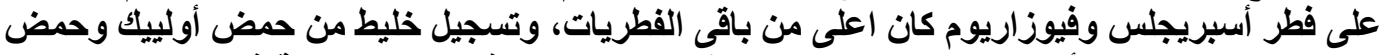

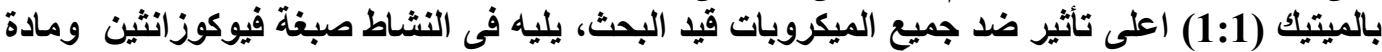

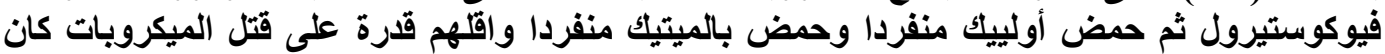

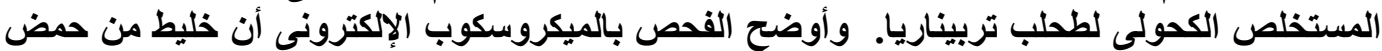

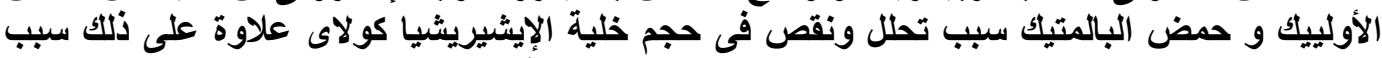

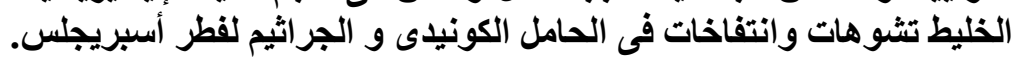

